\title{
Teaching legal terms in English and learning their functions and placements in a sentence, compared with Uzbek
}

\section{Shahribonu SIROJIDDINOVNA ${ }^{1}$}

Samarkand State Institute of Foreign Languages

\begin{tabular}{l} 
ARTICLE INFO \\
\hline Article history: \\
Received December 2021 \\
Received in revised form \\
15 December 2022 \\
Accepted 20 January 2022 \\
Available online \\
15 Fabray 2022 \\
\hline Keywords: \\
legal terminology, \\
linguistic communication, \\
correlation between \\
linguistic and jurisprudence.
\end{tabular}

ABSTRACT

The article examines the similar and distinguishable features of legal terms in different English speaking countries, together with Uzbek, and gives a rather useful data concerning the difficulties that may occur while translating and instructing legal English to the students of the faculties of law.

2181-1415/@ 2022 in Science LLC.

DOI: https://doi.org/10.47689/2181-1415-vol3-iss1/S-pp104-110

This is an open access article under the Attribution 4.0 International (CC BY 4.0) license (https://creativecommons.org/licenses/by/4.0/deed.ru)

\section{Ingliz tilida yuridik atamalarni o'qitish hamda ularning vazifasi va gapdagi joylashuvini o'zbek tili bilan solishtirgan holda o'rganish}

\section{Kalit so'zlar:}

huquqiy terminologiya,

lingvistik aloqa,

lingvistika va

huquqshunoslik o'rtasidagi

o'zaro bog'liqlik.
ANNOTATSIYA

Maqolada o'zbek tili bilan birgalikda ingliz tilida so'zlashuvchi turli mamlakatlardagi yuridik atamalarning o'xshash va farqli xususiyatlari ko'rib chiqilib, yuridik fakultet talabalariga yuridik ingliz tilini tarjima qilish va o'rgatishda yuzaga kelishi mumkin bo'lgan qiyinchiliklar haqida juda foydali ma'lumotlar keltirilgan.

\footnotetext{
1 Teacher at the Samarkand State Institute of Foreign Languages. Samarkand, Uzbekistan.
} 


\section{Преподавание юридических терминов на английском языке и изучение их функций и места в предложении по сравнению с узбекским}

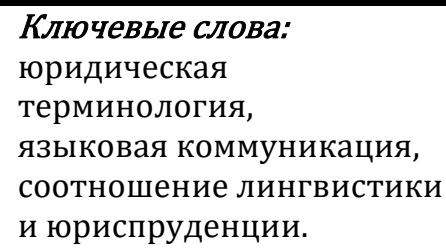

\begin{abstract}
АННОТАЦИЯ
В статье рассматриваются сходные и отличительные черты юридических терминов в разных англоязычных странах, в том числе узбекских, и приводятся весьма полезные данные о трудностях, которые могут возникнуть при переводе и обучении юридическому английскому языку студентов юридических факультетов.
\end{abstract}

Legal terminology is widely used not only in the professional environment, but also in other areas of linguistic communication, therefore there is a great demand for the study of the language of law for special purposes.

Legal terminology is a unique object of research, as it is characterized by a wide variety of fields of application in comparison with other terminological systems. According to the UK Legal Genres Commission, there are about seventy types of text used in the professional field. This genre diversity is due to the multiplicity of sources of law and the development of the Anglo-Saxon legal family, which includes, first of all, the legal systems of the United States and Great Britain.

It is rather difficult to carry out a comparative study of the systems of legal terms and concepts in English and Uzbek, since it is not so much when the terms themselves are compared, but different legal systems (as you know, there are deep differences between Uzbek codified and Anglo-American case law, which are manifested, among other things, and at the level of terminology). Dictionary correspondence often does not give a correct idea of the lexical unit, since behind similar terms in two languages there are different concepts or a different amount of meaning of concepts that are close in meaning. For example, "prosecutor" is translated "prosecutor", but the functions of these figures in the systems of American and Uzbek law do not coincide, and an American, hearing the word "prosecutor", imagines something different from what a Uzbek-speaking carrier means in the word "prosecutor".

In this regard, in our opinion, there is an urgent need to conduct not just a comparative analysis of individual terms and describe the ways of their translation from English into Uzbek or from Uzbek into English, but to conduct a comprehensive contrastive study of terminological systems in individual branches of law.

For this, first of all, it is necessary to determine the status of the term in the lexical system of the language and the signs that distinguish it from non-terminological tokens. F. de Saussure sees the main difference between terms and common words in the following: "The word as a sign has an unmotivated, arbitrary nature, and the term is a sign of a special semiotic system that has a nominative-definitive function: nominative because the term (as a word) denotes a whole complex a fragment from the general system of meanings" [1. PP. 126-127].

When comparing a word and a term, the following features of the latter can be distinguished:

1. the correlation of meaning not with a separate object or phenomenon, but with a class or kind of objects or phenomena; 
2. correlation not with an everyday concept or a general idea, but with a scientific or technical concept;

3. the need for a term to function within a strictly defined terminology system; a term is always a member of a terminology system;

4. a higher degree of abstraction from reality, up to a break with it;

5. connection of a term with a certain professional activity, which requires certain knowledge and training for the use of terminological vocabulary. [see details 2].

The above mentioned differences between the terminology and common vocabulary have been identified by linguists. It is interesting to analyze what sorts of criteria are put forward by lawyers when considering the issue of the distinguishing features of a legal term. Let us turn to the fundamental research "Legal terminology: formation and composition" by S.P. Khizhnyak, in which the classification of signs presented to the term by lawyers is given. According to the author, the term should be:

1. uniform, that is, used in a given law or other normative act in the same sense, to be unambiguous within one system;

2. generally recognized, and not invented by the legislator only for this case, it is unacceptable to use the term in any special sense;

3. stable, that is, the meaning and meaning of the term should not change depending on the context;

4. logically related to other terms of this system;

5. correlated with the professional field of use [see 3].

If we compare the groups of features discussed above, it becomes obvious that lawyers and linguists understand somewhat different things by the term, although there are similar criteria. The understanding of lawyers is much broader, since they classify even words that are used in the texts of laws in their basic general linguistic meaning to the category of terms. From the point of view of a more rigorous linguistic approach, such lexemes cannot be classified as terms, since there is no sufficient basis for the termination of these concepts.

Both lawyers and linguists celebrate independence as the bridging of the term from the context, while the meaning of the term is revealed in its definition, and not in the context, as is the case with common vocabulary. Thus, the word passes from the general literary language to the professional language and becomes an element of the terminology system.

Unfortunately, a more detailed analysis of the differences in approaches to the problem of vocabulary termination from the point of view of legal or linguistic analysis is beyond the scope of this article and requires further development. The purpose of our brief review was to demonstrate that the development of a holistic concept of legal terminology requires a combination of the approaches of representatives of different sciences and is currently at the stage of formation.

For a clearer description of legal terminological systems, it is necessary to develop a classification of terms in a given subject area, in connection with which there is a need to choose a classification basis. One of such grounds may be the factor of a word belonging to a sublanguage of a certain field of activity. Let us dwell in more detail on the previously developed classifications of legal terminology.

The classification developed by A.S. Pigolkin is carried out according to vertical and horizontal principles. At the top of the vertical classification will be the terminology enshrined in the Basic Law and other legislative acts, that is, general legal terminology that unites terms used in all branches of law and denoting the broadest concepts. 
Horizontal terminology encompasses various types of cross-industry and industryspecific terminology. Interdisciplinary terminology is terms used in several branches of law. The main volume of legal terms falls on cross-sectoral terminology, while the number of sectoral terms is relatively small [4].

We find a slightly different classification in D.I. Miloslavskaya [5], which distinguishes the following groups of terms:

1. common use;

2. commonly used, having a narrower, special meaning in a normative act

3. purely legal;

4. technical.

There are other classifications of legal terminology, however, for the purposes of this article, the above classification grounds are sufficient.

The terminology of the legal sphere differs from the terminology systems of other areas of knowledge. One can note the significant influence of Latin on the formation of legal terminology, which led to the loss of the connection between the legal and general literary languages. Legal terminology in the process of the formation of legal institutions in England separated from the common language and became understandable only to the initiated. Words borrowed from Latin have become highly specialized (researchers note that up to $10 \%$ of direct Latin borrowings have survived). Another feature can be considered the fact that in legal terminological systems a special unity of lexical units is created, their special compatibility and special connections between words, there is a differentiation of the wide and narrow meaning of the word within the framework of a given terminological field (for example, in the legal language, words such as "right", "totality", "composition", etc.).

We believe that for the convenience of analysis, legal vocabulary can be divided into classes according to the method of concept nomination (terms, terminonyms, professionalisms). Another parameter is belonging to a certain branch of law, which gives grounds for classifying a lexeme as a general legal or branch vocabulary (the meanings of branch terms can be adequately understood only in the subsystem of the corresponding branch of law). The third parameter of the classification of special vocabulary is the highlighting of realities, which are represented by toponyms, anthroponyms, appellatives and phraseological units: Old Baily - Old Bailey, Central Criminal Court, toponym by the name of the street in London where it is located; Miranda warning - the official announcement to the suspect of his rights, anthroponym after the name of the famous court case "Miranda v. Arizona" (1966); pocket veto - "pocket veto", an indirect veto of the President of the United States, an appellate (common noun).

The classification grounds for the belonging of a term to a certain class, for the method of nomination and for identifying the type of reality are relevant both for describing the terminological systems of one language, and for contrastive studies. When comparing the legal terminology of the English and Uzbek languages, other classification features appear.

In addition, there are differences in the use of legal terminology in American and British English.

Here are some typical examples:

- Ministry of Foreign Affairs: State Department (USA) - Foreign and Commonwealth Office (UK); 
- Ministry of Finance: Treasury Department (USA) - Treasury (UK);

- Department of Justice: Department of Justice (USA) - Department for Constitutional Affairs (UK);

- Ministry of Education: Department of Education (USA) - Department for Educational Skills (UK);

- Attorney General: Minister of Justice (USA) - Attorney General (UK).

These differences represent significant difficulties for translation, since they are practically not recorded in bilingual dictionaries.

Another typical example of the specificity of the British and American terminological systems is the classification of crimes. This topic is considered in detail in the work of E.S. Maksimenko [6].

Initially, the classification system in English and American legal terminology was the same. All crimes were subdivided into felonies, misdemeanours and treasons with the generic term crime. According to the old classification, felony was subdivided into: felony at common law, capital felony, statutory felony. Misdemeanor included two classes: misdemeanor at common law, high misdemeanor.

According to the old classification, the microfield, represented by the generic term felony, included nominees for treason and sedition. This classification of crimes has existed in English and American law since the late 19th century. However, in 1967, a new classification appeared in English legal terminology, based on the selection of the object of the crime itself. In English legal terminology, the term "offense" has become the generic term for the taxonomic structure under consideration. The term crime has come to refer to concepts previously expressed by the terms felony and misdemenour. Instead of the terms felony, misdemenour and treason, compound terms are used, formed on the basis of the term crime with various distributors, limited by prepositional constructions: crime - crime against the state, crime against justice, crime against religion, crime against reputation, crime against security, crime against morality etc.

In accordance with the new established model of legal culture, there was a further redistribution of existing terms by microfields. Thus, crime against reputation include: libel (a method of defamation expressed by print, writing, pictures, or sign), defamation (an intentional false communication, either published or publicly spoken, that injures another's reputation or good name), slander (speaking of defamatory words tending to prejudice another in his reputation, community standing, office, trade, business or means of livehood) (see Black's Law Dictionary).

In modern American legal terminology, an old classification borrowed from English law has been preserved, combining the concepts expressed by the terms felony and misdemeanor.

The generic term in American taxonomy, unlike English, is the term crime, not offence. The term criminal offenses includes offenses against persons (for example, murder, manslaughter), offenses against habitation and occupation (for example, burglary, arson), offenses against property (for example, larceny), offenses against morality and decency (for example, adultery), offenses against public order and government (for example, treason).

In addition, in the American legal system, there is a classification of crimes according to the degree of severity, according to which the term crime has specific nominees, which are differentiated using the letter indices A, B, C, for example, A felony, B felony, C felony and A misdemeanor. B misdemeanor, C misdemeanor. Such a classification did not and does not exist in English criminal law. 
The listed differences in English and American terminology cause difficulties in translating the corresponding terms into Uzbek, since the Uzbek legal system has its own classification of crimes, which differs from both the British and American versions. In a comparative analysis of terminology, it is necessary to take into account that the terminological systems are based on different legal doctrines: European-Turkic for the Uzbek legal system and Anglo-Saxon for English and American law. The continental legal system has a number of differences from the Anglo-American system. So, for example, a characteristic feature of the latter is the division into statute law and common law. The source of statutory law is legislation. Common law is made up of a large number of judicial precedents, that is, decisions that establish a certain legal principle (ratio juris), which are binding on a similar case. Thus, a legal role is recognized for the precedent.

The peculiarities of the legal doctrine affect the use of terminology, therefore, the selection of equivalent correspondences for an adequate translation of terms is possible only after studying the relationships within each terminological system, as well as after studying the intersystem relationship of terms. It should be emphasized once again that the object of research in this case is not individual terms, but the corresponding terminological fields.

A comparative study of Uzbek and English legal terminology is of great importance not only in theoretical but also in practical terms. This is due to the acute shortage of textbooks and dictionaries for legal translation. There is an urgent need to train specialists who can accurately translate legal texts of different genres in written and oral form. Without special textbooks and dictionaries, such a task is difficult to accomplish, since at present students are offered legal translation manuals containing translation equivalents of individual terms and terminological phrases without any connection with integral terminological systems. At the same time, the task is not posed to get acquainted with the differences between the two legal systems, although without studying the relationship of Anglo-American legal terms with their Uzbek equivalents, a high-quality special translation is impossible.

\section{REFERENCES:}

1. F. de Saussure. Works on linguistics. - M.: Progress, 1977,

2. Kobrin B.N., Golovin R.Yu. Linguistic foundations of the doctrine of terms. - M.: Higher. shk., 1987. - P. 104.

3. Khizhnyak S.P. Legal terminology: Formation and composition. - Saratov, 1997. - P. 137.

4. Pigolkin A.S. The language of the law. - M. 1990.

5. Miloslavskaya D.I. Typical difficulties in the semantic interpretation of a legal text. - In collection: Russian language in its natural and legal existence. - Barnaul: ASU Publishing House, 2000. - P. 272.

6. Maksimenko E.S. National and cultural specificity of industry terminology systems (based on the material of English and American legal terminology). - Author's abstract. Ph.D. thesis ..., M., 2002.

7. Makhmonov L.S., Yigitov A.U., Amerova D.A., \& Temirov N.N. (2021). Coordination of treatment guidelines for iron deficiency and b12 deficiency anemia associated with helicobacter pylori. nveo-natural volatiles \& essential oils Journal | NVEO, 10175-10182. 
8. Махмонов Л.С., Ризаев Ж.А., \& Гадаев А.Г. (2021). Helicobacter pylori ва уни темир хамда витамин в12 танқислиги камқонлиги юзага келишидаги ахамияти.

9. Shahram A., Umida, K., \& Zarina, R. (2020). Information technology's role in the study of foreign languages. Asian Journal of Multidimensional Research (AJMR), 9(3), 96-98.

10. Sherzodovich A.S. (2020). The role of online teaching and innovative methods. Science and education, 1(3), 524-528. 